\title{
From Jenner to Jerne: Towards Idiotype Vaccines
}

\author{
Fons G. C. M. UytdeHaag ${ }^{1}$, Hans Bunschoten' ${ }^{1}$, Kees Weijer ${ }^{2} \&$ \\ Albert D. M. E. Osterhaus'
}

\section{INTRODUCTION}

In 1798 Edward Jenner introduced vaccination against an infectious agent, i.e. smallpox, a discovery which was only fully appreciated 80 years later through the demonstration by Louis Pasteur of a vaccine prophylaxis for chicken cholera. Vaccination with both live and inactivated vaccines has proved to be a major contribution in controlling infectious diseases of man and animals. Vaccination with this first generation of vaccines is, for certain vaccines, still accompanied by serious complications, such as side effects, incomplete protection and problems with large-scale production.

An important move towards the creation of safer vaccines was made by Goebel (Goebel 1938) when he designed a synthetic vaccine conferring protective immunity to mice against pneumococci type III. Recently, on the basis of sequence data, peptides structurally resembling viral antigens have been synthesized, which are capable of inducing antibodies reactive with native viral antigens (Gerin et al. 1983, and see Lerner 1982 for review). More often, however, synthetic peptides proved weak immunogens and their future applicability for vaccination will depend on the development of new methodologies, aiming at the improvement of their immunogenicity (Stewart-Tull 1985).

The use of bacteria and eukaryotic cells for the expression of heterologous antigens - the recombinant DNA technology - has presented the opportunity for large-scale production of antigens free of contaminating material which cannot be produced in conventional systems. An exciting recent advance is the utilization of vaccinia virus as a vector for genes encoding proteins of pathogens. This approach has already proved to be effective in the resistance to infections with rabies virus, influenza virus and herpes simplex virus (see Quinnan 1985 for review).

\footnotetext{
'National Institute of Public Health and Environmental Hygiene, Bilthoven, and ${ }^{2}$ The Netherlands Cancer Institute, Amsterdam, The Netherlands.
} 
Almost two centuries after Jenner's introduction of vaccination against smallpox, Niels Jerne (Jerne 1974) proposed his network theory of the immune system which constitutes the theoretical basis for the construction of idiotype vaccines (Nisonoff \& Lamoyi 1981). In his theory, Jerne postulated the mutual recognition of idiotopes in the immune system during a normal "non-immune state", resulting in a permanent communication between the elements of the system. Antibody produced in response to external or internal stimuli (Ab1) is regulated by antibody (Ab2) recognizing idiotype specificities of Ab1. Experiments using a cascade of immunizations (Ab1, Ab2, Ab3 etc.) support the concept that idiotypes may function as targets for regulatory signals (Urbain et al. 1977 Cazenave 1977, Bona et al. 1981).

\section{THE IDIOTYPIC CASCADE AND INTERNAL IMAGES}

According to Jerne (Jerne et al. 1982), 2 types of anti-idiotypic antibodies can be distinguished: Ab2a anti-idiotypic antibody that recognizes through its paratope an idiotope associated with the framework or the paratope of Abl. The binding of $\mathrm{Ab} 2 a$ to $\mathrm{Ab} 1$ may or may not interfere with the binding of the paratope of Abl to its corresponding epitope. Ab2 $\beta$, anti-idiotypic antibody that binds, like the antigen with its epitope, through its idiotope to the paratope of Abl and consequently can replace external and self-antigen in inducing antigen-specific responses: they may constitute the internal images of epitopes (Fig. 1). In addition to Ab2a and Ab2 $\beta$, another set of Ab2 was described by Bona et al. (1982). $\mathrm{Ab} 2 \varepsilon$, anti-idiotypic antibody (epibody) specific for both an idiotope and an epitope. Ab2 $\varepsilon$ antibodies were described as antibodies that not only bind to the Fab fragment (idiotope) of human $\operatorname{IgM}$ with rheumatoid factor activity but also to the Fc fragment (epitope) of human IgG. (Bona et al. 1982, Chen et al. 1985). Although this set of $\mathrm{Ab} 2 \varepsilon$ seems restricted to certain rheumatoid factors, its demonstration illustrates that the classification of antibodies in Ab1, Ab2 etc., is not governed by any general principle.

From experiments exploring the idiotypic cascade (Urbain et al. 1977, Cazenave 1977, Bona et al. 1981) it has become clear that the type of response following immunization with Ab2 - Ab3 response - varies with the type of Ab2 used for immunization (Urbain et al. 1983). The Ab3 response may consist of "alpha" Ab3 which neither shares idiotopes with Abl nor exhibits epitope binding specificity similar to that of Ab1: it just recognizes Ab2 idiotopes (Urbain et al. 1977, Cazenave 1977). "Beta" Ab3 shares idiotopes of Abl but does not bind antigen. Ab3 responses have often been shown to be dominated by this kind of molecule. In most cases, subsequent immunization with antigen has been required to reveal that another, 3rd subset, "gamma" Ab3, has also been primed by Ab2, which shares idiotopes with Abl and binds the same epitopes (Wickler et al. 1979, Bona et al. 1981, Bluestone et al. 1981, Takemori et al. 1982). Ab3 "alpha", "beta" 


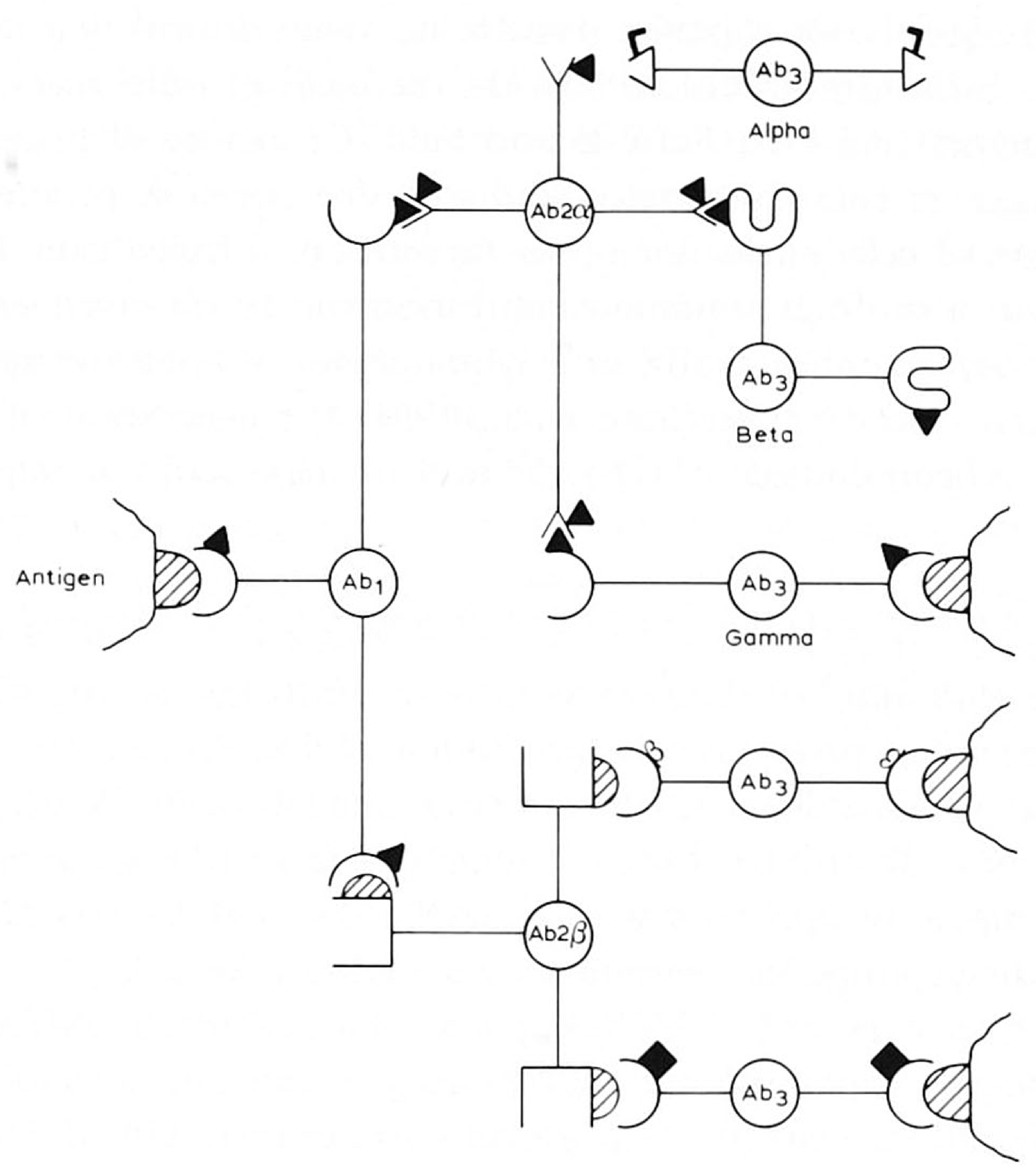

Figure 1. Sets of antibodies involved in idiotypic networks (Jerne 1974).

and "gamma" are induced by Ab2a. The 4th subset of Ab3 induced by Ab2 $\beta$ is able to bind antigen but does not necessarily share idiotopes with Abl. The induction of predominantly Abl idiotype-bearing antibody ("beta" and "gamma" $\mathrm{Ab} 3)$ by $\mathrm{Ab} 2 \alpha$ and of antigen-binding $\mathrm{Ab} 3$ by $\mathrm{Ab} 2 \beta$ suggests that $\mathrm{Ab} 2$ can substitute for antigen for the induction of protective immunity (Fig. 1). For obvious reasons, future Ab2 vaccines should be composed of panels of monoclonal antibody reagents (see Sacks et al. 1983 and UytdeHaag and Osterhaus 1985).

In describing the research on the potential of $\mathrm{Ab} 2$ for the induction of protective immunity, which we recently started in our laboratory, we will touch upon the use of monoclonal Ab2 defining private, interstrain recurrent or interspecies recurrent idiotopes to induce - in the absence of antigen - immune response against feline leukemia virus, rabies virus and poliovirus.

\section{AB2 DEFINING PRIVATE IDIOTOPES}

(FELINE LEUKEMIA VIRUS AS A MODEL)

Of the structural proteins of feline leukemia virus (FeLV), only the envelope glycoprotein - GP70 - which is disulfide-linked to the protein in the virion lipid 
bilayer - p15(E) - is shown capable of inducing virus neutralizing antibodies (Bolognesi et al. 1978, Grant et al. 1980). On the basis of differences in GP70 structure, 3 serotypes (FeLV-A, FeLV-B and FeLV-C) can be distinguished, of which FeLV-A is most commonly associated with degenerative, proliferative or neoplastic changes of cells of the hemopoeietic series in infected cats. In persistently infected cats a profound immunosuppression can be observed which may be related to the replication of FeLV in T lymphocytes. Among the approaches to develop a FeLV vaccine (Osterhaus et al. 1985) the generation of an antiidiotypic vaccine is being considered (Osterhaus et al., manuscript in preparation).

\section{Production and characterization of a panel of monoclonal Ab2 (MoAb2)}

$\mathrm{BALB} / \mathrm{c}$ MoAb1 with anti-GP70 intertypic cross-neutralizing activity (Osterhaus et al. 1985) were used as probes for the generation of BALB/c MoAb2. MoAb1, 3-17, 6-15 and 7-3 derived from one fusion event and MoAb1 25V, 60I and 46II were generously provided by Dr. Lutz (Veterinairy Medical Laboratory, Zurich, Table I). In a competition ELISA it was found that MoAbl 3-17, 6-15 and 7-3 recognized the same epitope representing a neutralization inducing site on GP70 shared by the 3 serotypes of FeLV (Weijer et al., submitted). MoAb1 were purified by protein-A Sepharose chromatography, coupled to Keyhole Limpet Hemocyanin (KLH) and subsequently used for the production of MoAb2 by immunization of $\mathrm{BALB} / \mathrm{c}$ mice. Fifteen stable MoAb2-producing hybridomas

TABLE I

Characteristics of anti-FeLV MoAbl

\begin{tabular}{lcccccccc}
\hline & & \multicolumn{3}{c}{ Neutralization $^{\text {d }}$} & \multicolumn{3}{c}{ Fluorescence $^{\mathrm{c}}$} \\
MoAb & ELISA $^{\mathrm{c}}$ & A & B & C & A & B & C & Specificity $^{\mathrm{f}}$ \\
\hline $7-3^{\mathrm{a}}$ & $1.2 \times 10^{\mathrm{s}}$ & 5120 & 2560 & $10^{4}$ & $\geq 5$ & $\geq 5$ & $\geq 5$ & anti-GP70 \\
$6-15^{\mathrm{a}}$ & $2.5 \times 10^{5}$ & 1280 & 2560 & 2560 & $\geq 5$ & $\geq 5$ & $\geq 5$ & anti-GP70 \\
$3-17^{\mathrm{a}}$ & $5 \times 10^{5}$ & 5120 & 5120 & 5120 & $\geq 5$ & $\geq 5$ & $\geq 5$ & anti-GP70 \\
$25 \mathrm{~V}^{\mathrm{b}}$ & $1 \times 10^{6}$ & 320 & $<2$ & 50 & $\geq 5$ & $\geq 5$ & $\geq 5$ & ND \\
$60 \mathrm{I}^{\mathrm{b}}$ & $3 \times 10^{4}$ & $\mathrm{ND}$ & $\mathrm{ND}$ & $\mathrm{ND}$ & 3.5 & 1.5 & 3.5 & ND \\
$46 \mathrm{II}^{\mathrm{b}}$ & $1 \times 10^{6}$ & 5120 & 4 & 800 & $\geq 5$ & $\geq 5$ & $\geq 5$ & ND \\
\hline
\end{tabular}

${ }^{a}$ MoAbs derived from the same fusion.

${ }^{b}$ MoAbs were provided by Dr. A. Lutz.

c ELISA on microtiter plates coated with $0.1 \mu \mathrm{g}$ FeLV/well.

d Neutralization focus assay with MSV (FeLV-A, $-\mathrm{B}$, or $-\mathrm{C}$ ) as virus.

' Membrane fluorescence on FL74 cells (containing FeLV subgroups A, B and C) as targets. Titer $=\log 10$.

' Determined by Western blot analysis with purified FeLV analysed in 7.5\% SDS-PAGE, $20 \mu \mathrm{l}$ of MoAb, and goat anti-mouse IgG ( $\mathrm{Fc}$ fragment-specific) perioxidase conjugate (Osterhaus et al. 1985).

$\mathrm{ND}=$ not determined. 
were obtained out of a total of 4 fusions (Table II). Competition ELISA was used to test whether each of the MoAb2 recognized an idiotope associated with either the framework or the paratope of MoAb1, 3-17. The binding of each of the MoAb2 to MoAb1, 3-17 could be inhibited by FeLV, suggesting that these idiotopes are located within or near the combining site of MoAbl, 3-17.

In order to further characterize the specificity of MoAb2, a series of competition studies was performed. The ability of the different MoAbl and of antiFeLV hyperimmune sera of BALB/c mice, rats, guinea pigs, cats, goats or rabbits to compete with plate-bound MoAb1, 3-17 for the binding to fixed amounts of each of the MoAb2 was investigated in an ELISA system. The results of these experiments showed that binding of each of the MoAb2 to MoAb1, 3-17 could be inhibited by the homologous MoAbl, 3-17, and by 6-15 and 7-3 which, as stated, all derived from the same fusion event and which recognize the same epitope on FeLV, but not by any of the polyclonal sera from the respective animal species tested. Thus, all MoAb2 seem to be directed against non-recurrent (private) idiotopes of MoAbl, 3-17.

To find out whether the different MoAb2 recognize different idiotopes on MoAb1, 3-17, ELISA inhibition studies were performed in which the capacity of each of the MoAb2 to inhibit the binding of labeled MoAb2, 2-17 to platebound MoAbl, 3-17 was investigated. The results of these experiments allowed the division of MoAb2 into 2 groups. The 1st set MoAb2 showed a complete or partial inhibition, indicating that the detected idiotopes are identical to the one recognized by MoAb2, 2-17, or are different, partially overlapping idiotopes, respectively. None of the MoAb2 of the 2nd set showed such inhibition, suggesting that at least 2 different idiotopes on MoAb1, 3-17 were recognized by the panel of MoAb2 (Table II).

Induction of "silent" idiotopes: immunization with MoAb2, 2-17

Obviously, the most promising candidates for idiotype vaccines are either Ab2a defining interspecies recurrent idiotopes, or Ab2 $\beta$ mimicking antigenic structure.

TABLE II

Characteristics of $\mathrm{MoAb2}^{(\mathrm{a})}$

\begin{tabular}{|c|c|c|c|c|}
\hline & MoAb2 & & Specificity & $\begin{array}{l}\text { Inhibition of binding of } \\
\text { MoAb2, 2-17-HRPO to } \\
\text { MoAb1, 3-17 }\end{array}$ \\
\hline Group I & $\begin{array}{c}2-17, \quad 1 \mathrm{~A}, \\
1 \mathrm{C} \\
14 \mathrm{~B}, \quad 15 \mathrm{~B},\end{array}$ & $\begin{array}{l}21 \mathrm{~A} \\
12 \mathrm{~B} \\
19 \mathrm{~B}\end{array}$ & $\begin{array}{l}\text { private } \\
\text { and } \\
\text { paratope-related }\end{array}$ & partial or complete \\
\hline Group II & $\begin{array}{l}1 \mathrm{~B}, \quad 2 \mathrm{~A} \\
5 \mathrm{~A},\end{array}$ & $\begin{array}{l}4 \mathrm{~B} \\
6 \mathrm{~B} .\end{array}$ & $\begin{array}{l}\text { private and } \\
\text { paratope-related }\end{array}$ & none \\
\hline
\end{tabular}

For details see text. 
However, Ab2 not displaying these properties may also be considered for immunization purpose. Numerous experiments have shown that Ab2a with specificity for either intrastrain recurrent or private idiotopes can promote the synthesis of antibodies of predetermined antigen specificity (Bluestone et al. 1981, Takemori et al. 1982, Urbain et al. 1983), even across allotype, linkage or species bariers (Hiernaux et al. 1981, Pene et al. 1983, Francotte \& Urbain 1984, Slaoui et al. 1985, reviewed by Sacks et al. 1983). These experiments encouraged us to investigate whether MoAb2, 2-17 defining private idiotopes of MoAb1, 3-17 can induce the generation of antibodies sharing idiotopes and FeLV-binding activity with MoAb1, 3-17.

We injected BALB/c mice intraperitoneally 4 times at weekly intervals with 10 $\mu \mathrm{g}$ MoAb2, 2-17 in saline, copolymerized with LPS, coupled to KLH, or with LPS alone. Immune responses were analysed over a period of $8 \mathrm{wk}$. Mice injected with MoAb2, 2-17 or with LPS alone induced no Ab3 response as detected by binding to plate-bound MoAb2, 2-17 f(ab)2 in ELISA. In contrast, injection of MoAb2, 2-17 coupled to LPS or KLH, resulted in clear Ab3 responses (data with MoAb2, 2-17-KLH, not shown). The titers of Ab3 were generated within $2 \mathrm{wk}$ and remained at the same level during the further course of the experiment. In addition to $\mathrm{Ab} 3$ responses, the presence of anti-FeLV activity in these sera was tested: antibodies against plate-bound FeLV were not detectable in an ELISA after immunization with MoAb2, 2-17-LPS or MoAb2, 2-17-KLH (Table III). Thus, the injection of MoAb2, 2-17 may trigger the production of antibodies binding only the injected anti-idiotypic antibody MoAb2, 2-17 and which lack anti-FeLV activity. The possibility cannot be excluded that Ab3 antibodies are present which do share idiotypic specificities with MoAb1, 3-17 and among which a small, in our assays undetectable, subset of FeLV-binding antibodies may be present. The availability of MoAb2 defining non-overlapping idiotopes

TABLE III

Induction of Ab3 response by immunization with MoAb2, 2-17

\begin{tabular}{llll}
\hline & \multicolumn{2}{l}{ Ab3 response (OD $\left.450 \mathrm{~nm} \times 10^{3}\right)^{\mathrm{b}}$} & \\
anti-MoAb2, 2-17 & post $(\mathrm{n}=5)$ & anti-FeLV \\
\hline Immunogen & pre & $1810(1409-2000)$ & none \\
\hline Ab2-LPS & $\leq 40$ & $\leq 40$ & none \\
Ab2 & $\leq 40$ & $\leq 40$ & none \\
LPS & $\leq 40$ & & \\
\hline
\end{tabular}

"mice were injected intraperitoneally 4 times at weekly intervals with $10 \mu \mathrm{g}$ MoAb2, 2-17 either in saline or copolymerized with LPS and with $10 \mu \mathrm{g}$ LPS alone.

${ }^{b}$ sera were analyzed before immunization and $2 \mathrm{wk}$ after the last immunization for expression of anti-MoAb2, 2-17 activity in ELISA and for anti-FeLV antibodies in ELISA's and membrane immunofluorescence (see lengend, Table I). No antibody activity against an irrelevant MoAb of the same subclasse (IgGl, $\varkappa$ ) was detectable (dilution of sera 1:45). 
of MoAb1, 3-17 could be a useful tool to investigate this issue, since co-expression of the MoAb1 idiotopes on antibodies induced by MoAb2, 2-17 would indicate that MoAb1, 3-17 idiotopes are expressed in a recurrent fashion in mice treated with MoAb2, 2-17. Such experiments are now in progress.

Thus, in contrast to what has been reported by Francotte and Urbain (Francotte \& Urbain 1984) - the induction of a silent idiotype of predefined antigen specificity, in absence of antigen, across a species barrier using polyclonal xenogeneic Ab2 defining a private idiotype - our results do not demonstrate that with one MoAb2 against a private idiotope antigen-binding antibodies can be induced, even in a syngeneic system. However, our results may be in general agreement with those of others (Bona et al. 1981, Rubinstein et al. 1983, Legrain et al. 1985) who showed that recurrent idiotypes were stimulated after injections with polyclonal or MoAb2 but that the generation of antigen-binding idiotype-positive antibodies required subsequent antigen triggering. At present we are investigating whether the administration of FeLV to MoAb2, 2-17-treated mice will induce the appearence of FeLV-binding antibody sharing idiotopes with MoAb1, 3-17.

\section{AB2 DEFINING INTERSTRAIN RECURRENT IDIOTOPES \\ (RABIES VIRUS AS A MODEL)}

Protective immunity against a rabies virus infection involves both neutralizing antibody response and cell-mediated immunity (Cox et al. 1977, Wiktor et al. 1974). The viral glycoprotein was shown to be of major functional importance for the triggering of both immune mechanisms (Wiktor et al. 1984a). Recently, evidence has been obtained for the existence of at least 5 functionally nonoverlapping antigenic sites on the rabies virus glycoprotein of the challenge virus standard (CVS) strain of rabies virus (Lafon et al. 1983, Wiktor et al. 1984b). Neutralization-resistant variant viruses could be generated in vitro by virus production in the presence of neutralizing anti-glycoprotein $\mathrm{MoAb}$, or in vivo by pre-treatment of mice with MoAb.

\section{Generation and characterization of MoAb2, 2-23}

We generated hybridoma's producing MoAbl by fusion of splenocytes from $\mathrm{BALB} / \mathrm{c}$ mice immunized with dog kidney cell vaccine (DKCV) against rabies virus with myeloma cells (Osterhaus et al. 1981). The fine specificity of 2 rabies virus neutralizing MoAb1, 1-10B8 and 1-11D6 could be mapped to one of the antigenic sites of the rabies virus glycoprotein using a panel of monoclonal antibodies against the various antigenic sites of rabies virus described by Lafon et al. (1983) and generously provided by Dr. T. Wiktor, Wistar Institute, Philadelphia, USA. In a competition ELISA with rabies virus as a solid phase and peroxidase labeled MoAb1, 1-10B8 we tested whether unlabeled homologous or 


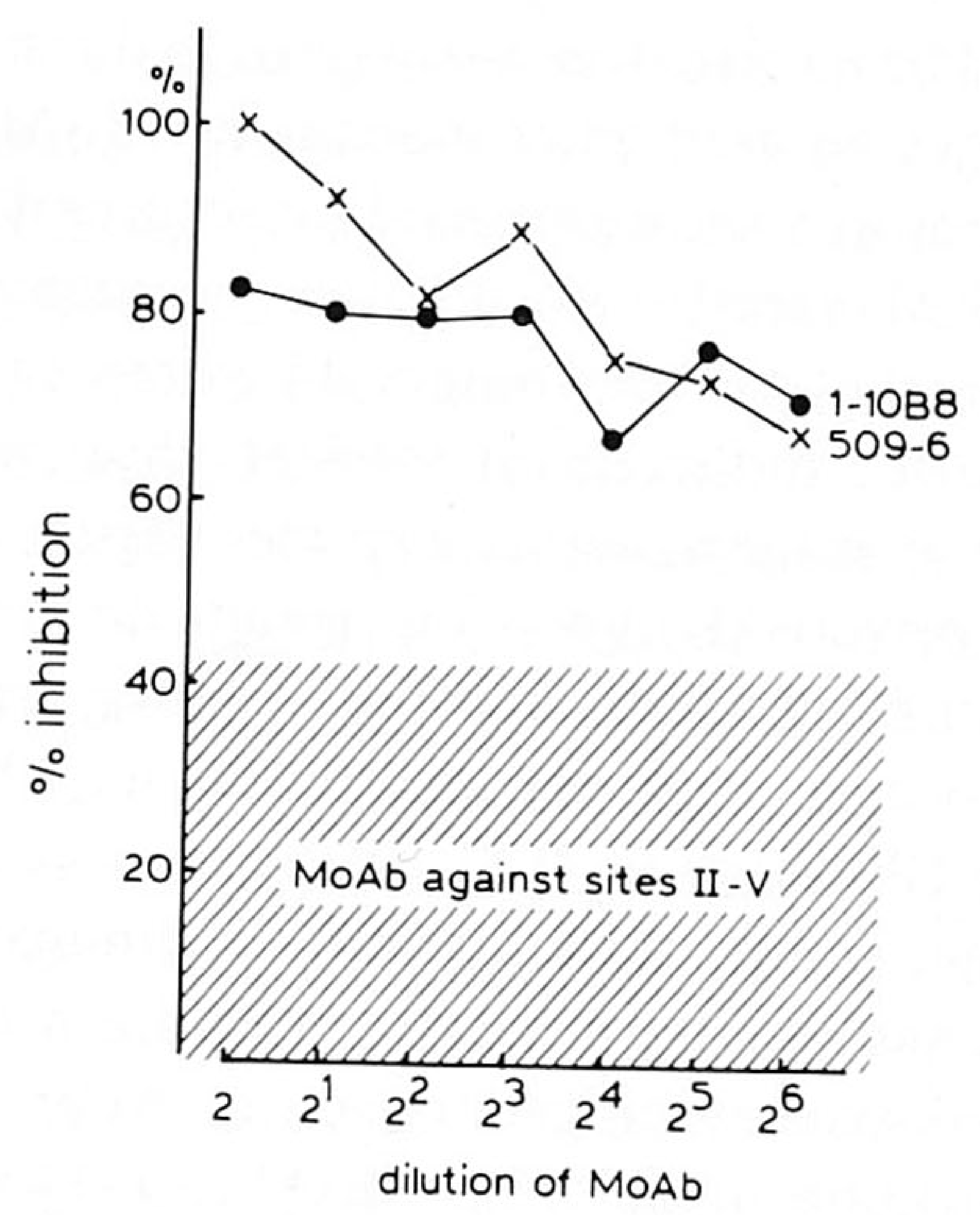

Figure 2. Epitope mapping of rabies virus neutralizing MoAb1, 1-10B8 in antigen-binding inhibition ELISA, using $40 \mathrm{MoAb}$ directed against 5 antigenic sites on the rabies virus glycoprotein. Inhibition of binding of MoAb1, 1-10B8-HPRO to plate-bound rabies virus (DKCV) by MoAb against the different antigenic sites of rabies virus glycoprotein is expressed as percentage inhibition of maximum binding of MoAb1, 1-10B8-HRPO without inhibitor.

heterologous Abl could compete for the binding of the labeled Abl with rabies virus. The results of these experiments indicate that MoAb1, 1-10B8 delineates the same antigenic site as MoAbl, 509-6 (Fig. 2). Essentially the same results were obtained with MoAb1, 1-11D6 (data not shown). This site-I was shown to represent a major neutralization-inducing site on rabies virus glycoprotein (Lafon et al. 1983). MoAb1, 1-10B8 was purified by protein-A sepharose chromatography, coupled to KLH and used for immunization of BALB/c mice to produce MoAb2 (Bunschoten et al., submitted). The presence of $A b 2$ was screened in ELISA on the basis of specific binding to MoAb1, 1-10B8 f(ab)2. We report here the characterization of a MoAb2, 2-23.

Using MoAb2, 2-23 as a reagent, we investigated whether the 1-10B8 idiotope was uniquely expressed on MoAb1, 1-10B8 (private idiotope) used for the generation and screening of MoAb2, 2-23 or whether it was also expressed on other MoAbl against the same or other antigenic sites of rabies virus glycoprotein (recurrent idiotopes). The results of these experiments, summarized in Fig. 3, show that homologous Ab1, 1-10B8 and heterologous MoAb1, 509-6 completely inhibit the binding of Ab2 to Ab1; similar results were obtained with MoAbl 1-11D6 (data not shown). The other 39 MoAb1 directed against other antigenic sites of rabies virus did not inhibit this reaction. Since MoAb1, 1-10B8, 1-11D6 and 509-6 obtained from T. Wiktor, were derived from different fusionevents 


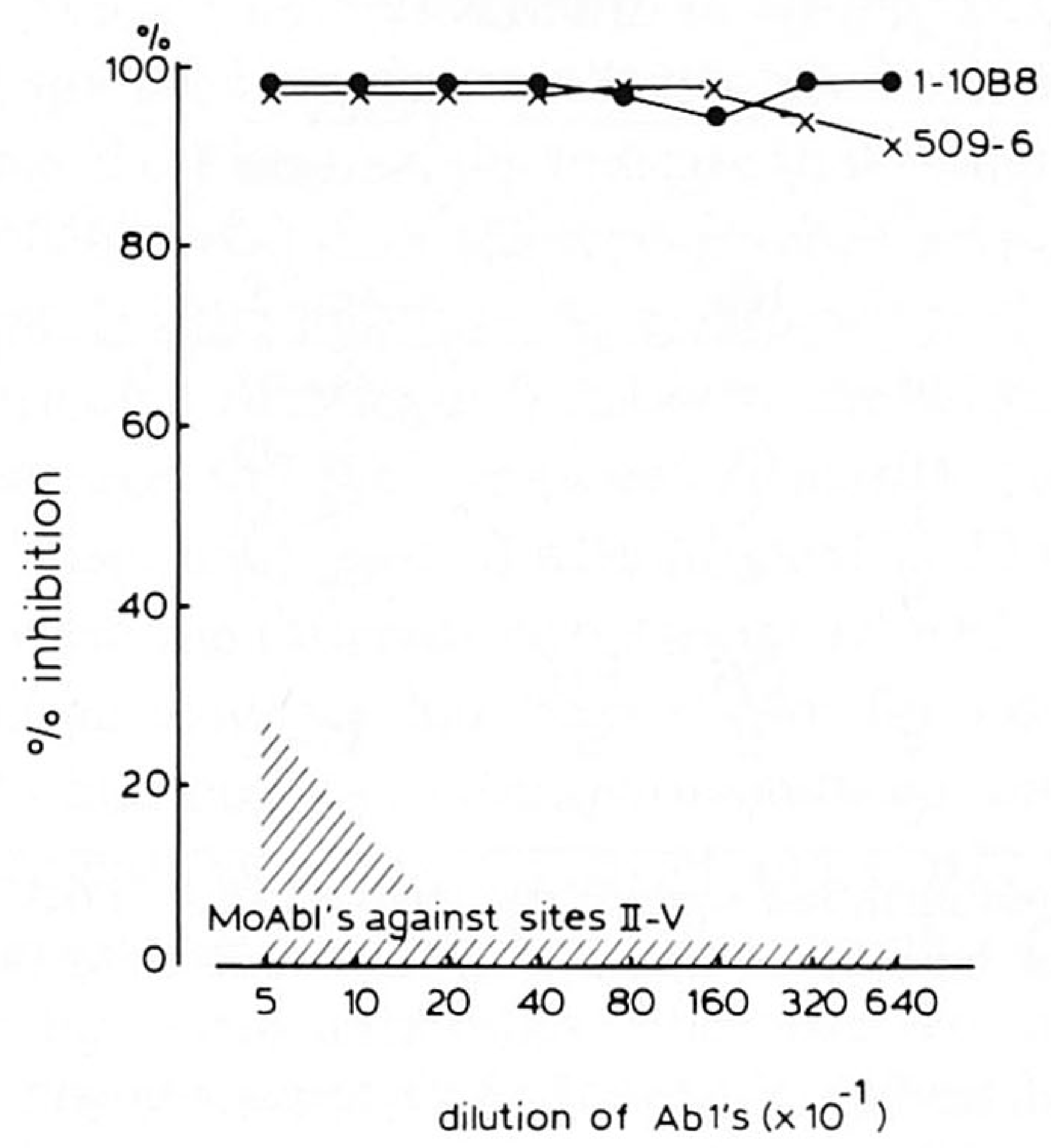

Figure 3. Inhibition of binding of MoAb2, 2-23 to plate-bound MoAb1, 1-10B8 by MoAb1 directed against different antigenic sites of rabies virus glycoprotein in ELISA. Coat: MoAb1, 1-10B8 f(ab)2. Conjugate: goat anti-mouse IgG (H-chain specific).

using the BALB/c hybridoma system, we concluded that the MoAb1, 1-10B8 idiotope is expressed in BALB/c mice in a recurrent fashion and in association with a B-cell response against the antigenic site-I of the rabies virus glycoprotein. Since the MoAb1, 1-10B8 idiotope expression was assumed to be associated with anti-rabies glycoprotein site-I activity, we investigated the ability of rabies virus to block the binding of MoAb2, 2-23 to MoAb1 1-10B8 $\mathrm{f}(\mathrm{ab})_{2}$ in ELISA under conditions at which MoAb2, 2-23 exhibited 90\% binding. The glycoprotein content of the rabies virus preparation used in this assay as inhibitor was estimated to be $20 \%$ of the total protein content. A dose-dependent inhibition was found with as much as $15 \mu \mathrm{g}$ inhibitor giving a maximum of $95 \%$ inhibition (data not shown). Similar results were obtained using HPLC-purified glycoprotein. Although steric hindrance may also have influenced this inhibition, the results suggest that the MoAb1, 1-10B8 idiotope is paratope-related.

When we investigated the sera of outbred NIH mice and human individuals immunized with DKCV, no expression of the 1-10B8 idiotope was found, despite the fact that, in all sera, antibodies were present against the antigenic site-I of the rabies virus glycoprotein. This suggested that the expression of the 1-10B8 idiotope might be regulated by MHC, Igh-C or Igh-V genes, as has been reported for the expression of recurrent idiotopes in other systems (Trenkner \& Riblet 1975, Takemori et al. 1982, Bluestone et al. 1981, Sacks \& Sher 1983, Rubinstein \& Bona 1983). This possibility was investigated by analysis of the immune responses to rabies virus of different inbred strains and congeneic strains of mice both at 
TABLE IV

1-10B8 idiotope expression in the anti-glycoprotein site-I response induced by rabies virus ${ }^{\mathrm{a}}$

\begin{tabular}{|c|c|c|c|c|c|}
\hline \multirow[b]{3}{*}{ Strain } & \multirow[b]{3}{*}{$\mathrm{H} 2$} & \multirow[b]{3}{*}{ Igh } & \multicolumn{2}{|c|}{ Anti-site-I } & $1-10 \mathrm{~B} 8 \mathrm{Id}^{\mathrm{c}}$ \\
\hline & & & \multicolumn{3}{|c|}{$\%$ inhibition } \\
\hline & & & & $(\mathrm{n}=5)$ & $(n=5)$ \\
\hline $\mathrm{BALB} / \mathrm{c}$ & d & a & & $86-92$ & $25-65$ \\
\hline BALB.B & b & a & & $78-92$ & $17-59$ \\
\hline C57BL 6 & b & b & & $76-90$ & $0-20$ \\
\hline C.B.20 & d & b & & $79-80$ & $0-10$ \\
\hline & & $\mathrm{CH}$ & $V H$ & & \\
\hline BAB. 14 & d & $\mathrm{b}$ & $\mathrm{a}$ & $87-92$ & $39-57$ \\
\hline BALB.Igb & $\mathrm{d}$ & $\mathrm{b}$ & b & $80-86$ & $0-10$ \\
\hline
\end{tabular}

$21 \mathrm{~d}$ after booster immunization with rabies virus vaccine (DKCV-150 $\mu \mathrm{g}$ ).

b ELISA: inhibition of binding of MoAb1, 1-10B8-HPRO to rabies virus (background values $\leq 30$ ).

' ELISA: inhibition of binding of MoAb2, 2-23 to plate-bound MoAb1, 1-10B8 f(ab)2 (background values $\leq 20$ ).

the epitope and idiotope level. Activation of anti-site-I MoAbl, 1-10B8 idiotopepositive clones was observed in BALB/c $\left(H-2^{d} \operatorname{IghC}^{a} V^{a}\right)$, BALB.B $\left(H-2^{b} \operatorname{IghC}^{a} V^{a}\right)$ and BAB.14 (H-2d $\left.\operatorname{IghC}^{\mathrm{b}} \mathrm{V}^{\mathrm{a}}\right)$ mice but not in C57BL/6 $\left(\mathrm{H}-2^{\mathrm{b}} \mathrm{IghC}^{\mathrm{b}} \mathrm{V}^{\mathrm{b}}\right)$, C. B20 (H$\left.2^{\mathrm{d}} \mathrm{IghC}^{\mathrm{b}} \mathrm{V}^{\mathrm{b}}\right)$ or BALB.Ig ${ }^{\mathrm{b}}\left(\mathrm{H}-2^{\mathrm{d}} \mathrm{IghC}^{\mathrm{b}} \mathrm{V}^{\mathrm{b}}\right)$ (Table IV). Thus, although mice of the latter 3 strains developed anti-site-I Abl antibodies in response to rabies virus, they did not express the 1-10B8 idiotope. These results clearly show that activation of anti-site-I 1-10B8 idiotope-bearing clones by rabies virus is associated with the IghV gene complex. Consequently, this may place major constraints on the possible use of MoAb2, 2-23 for vaccination of outbred populations. We shall approach this matter in the next section.

\section{Induction of recurrent idiotopes: immunization with MoAb2, 2-23}

In a number of systems evidence has been provided for a dose-dependent induction of idiotype response by Ab2. In addition, the manner of presentation of Ab2 to animals, i.e. in saline, CFA and coupled to KLH or LPS has been shown to influence the outcome of immunization with Ab2 (Eichmann 1974, see Sacks et al. 1983 for review). The capability of MoAb2, 2-23 to induce Ab3 antibodies with specificity for rabies virus in the absence of the virus was investigated by injecting BALB/c mice with different doses of MoAb2, 2-23 (100, 10, 1, 0.1 and $0.01 \mu \mathrm{g}$ ) either in saline or coupled to KLH and in CFA. It was found that mice injected with 0.1 or $0.01 \mu \mathrm{g}$ MoAb2, 2-23 did not develop Ab3 nor anti-rabies virus antibody. Two mice injected with 10 and $1 \mu \mathrm{g} \mathrm{Ab} 2$ in saline, respectively, developed Ab3 antibody possessing rabies virus-binding capacity. Injection with 
Ab2 coupled to KLH resulted in the induction of strong Ab3 response (5 out of 6) which in all cases was accompanied by the production of anti-rabies virusbinding antibody (Table V). These results indicate that immunization of BALB/ c mice with MoAb2, 2-23 may induce the expansion of anti-rabies virus-specific $\mathrm{B}$ cell clones bearing the 1-10B8 idiotope. As mentioned in the introductory part of this paper, it is difficult to distinguish between the different populations of antibodies which constitute the Ab3 response (Rajewsky \& Takemori 1983). Production of MoAb3 from mice injected with MoAb2, 2-23 will hopefully allow us to discriminate between the different populations of Ab3.

In the previous section evidence has been shown for $\mathrm{IghV}^{\mathrm{a}}$ gene-linked expression of the 1-10B8 idiotope in a rabies virus-induced anti-glycoprotein siteI antibody response. Immunization of C57BL/6 and C.B20 mice with $(100 \mu \mathrm{g})$ MoAb2, 2-23-KLH revealed further evidence, since neither C57BL/6 nor C.B20 mice developed anti-rabies virus antibodies. The observed inhibition by sera of C57BL/6 and C.B20 mice of the Ab2-Ab1 binding could be explained by an Ab3 response consisting of anti-Ab2 antibodies and of anti-allotype response (data not shown). It should be stressed that the conditions used to immunize C57BL/ 6 and C.B20 mice with MoAb2, 2-23 differed from those described for the induction of silent interspecies recurrent idiotopes across genetic bariers (Francotte \& Urbain 1984, Urbain et al. 1985). The authors demonstrated that it is possible to use polyclonal xenogeneic Ab2, not displaying the properties of an

TABLE V

Induction of anti-rabies virus antibodies in BALB/c mice by MoAb2, 2--23: effect of dosage and manner of presentation

\begin{tabular}{|c|c|c|c|c|}
\hline \multirow{3}{*}{$\begin{array}{l}\text { Dosage of } \\
\text { MoAb2, 2-23 } \\
\text { administered }\end{array}$} & \multicolumn{4}{|c|}{ Antibody response $\left(\right.$ OD450 $\left.\mathrm{nm} \times 10^{3}\right)$} \\
\hline & \multicolumn{2}{|c|}{$\begin{array}{l}\text { Ab3 response to } \mathrm{MoAb}^{\mathrm{a}} \text {, } \\
2-23 \text { given in: }\end{array}$} & \multicolumn{2}{|c|}{$\begin{array}{l}\text { Anti-rabies virus }{ }^{\mathrm{b}} \text { response } \\
\text { to MoAb2, } 2-23 \text { given in: }\end{array}$} \\
\hline & saline ${ }^{\mathrm{c}}$ & $\mathrm{KLH}^{\mathrm{d}}$ & saline & KLH \\
\hline \multirow[t]{3}{*}{$200 \mu \mathrm{g}$} & $\leq 250$ & 1251 & $\leq 30$ & 89 \\
\hline & $\leq 250$ & 1397 & $\leq 30$ & 346 \\
\hline & $\leq 250$ & 1599 & $\leq 30$ & 149 \\
\hline \multirow[t]{3}{*}{$20 \mu \mathrm{g}$} & $\leq 250$ & 1217 & $\leq 30$ & 104 \\
\hline & 267 & 1228 & $\leq 30$ & 81 \\
\hline & 1065 & N.D. & 376 & 323 \\
\hline \multirow[t]{3}{*}{$2 \mu \mathrm{g}$} & 717 & 250 & 143 & 30 \\
\hline & $\leq 250$ & $\leq 250$ & 49 & $\leq 30$ \\
\hline & $\leq 250$ & 292 & $\leq 30$ & $\leq 30$ \\
\hline
\end{tabular}

a ELISA: binding of mouse serum antibody to plate-bound MoAb2, 2-23 f(ab)2 detected by goat anti-mouse $\operatorname{IgG}$ ( $\mathrm{Fc}$ fragment specific)-HRPO.

${ }^{b}$ ELISA: binding of mouse serum antibodies to plate-bound rabies virus detected by goat anti-mouse IgG (Fc fragment specific)-HRPO.

c Two injections of 100,10 or $1 \mu \mathrm{g}$ were given intraperitoneally.

d Two injections of 100,10 or $1 \mu \mathrm{g}$ were given subcutaneously in CFA and IFA respectively. 
internal image, to induce in mice in a recurrent fashion the expression of a rabbit private idiotype. The $\mathrm{Ab} 2$ were directed against a private idiotype of rabbit $\mathrm{Ab} 1$ anti-TMV-specific antibody. In the induced Ab3 the appearance of anti-TMV antibodies sharing the idiotypes of Abl was observed. In order to obtain these results it was of crucial importance to couple Ab2 with LPS or to use dendritic cells pulsed with Ab2. Although these results imply that interspecies recurrent idiotopes can also be induced in outbred populations by $\mathrm{Ab} 2$ other than $\mathrm{Ab} 2 \beta$, the dependence on the use of polyclonal activators or pulsed, antigen-presenting cells will still place restraints upon the usefulness of such Ab2 for the induction of protective immunity.

\section{A regulatory role of the $A b 1,1-10 B 8$ idiotope?}

The analysis of anti-rabies virus glycoprotein site-I antibody responses of BALB/ $c$ and BALB.B mice immunized with rabies virus vaccine revealed evidence for a dominant expression of the recurrent 1-10B8 idiotope. It appeared that the 1-10B8 idiotope-bearing antibodies make up a significant (30\%-90\%) proportion of the antibodies against rabies virus glycoprotein site-I (Fig. 4). The observations were confirmed using in vitro stimulation with rabies virus of lymphnode cells from BALB/c mice primed in vivo with virus. Dominant expression of the MoAbl, 1-10B8 idiotope in an anti-rabies virus glycoprotein site-I response may suggest that priming of the relevant $\mathrm{B}$ cells has already occurred previous to contact with this epitope. Clearly, detailed investigations of the precursor frequency of Abl,

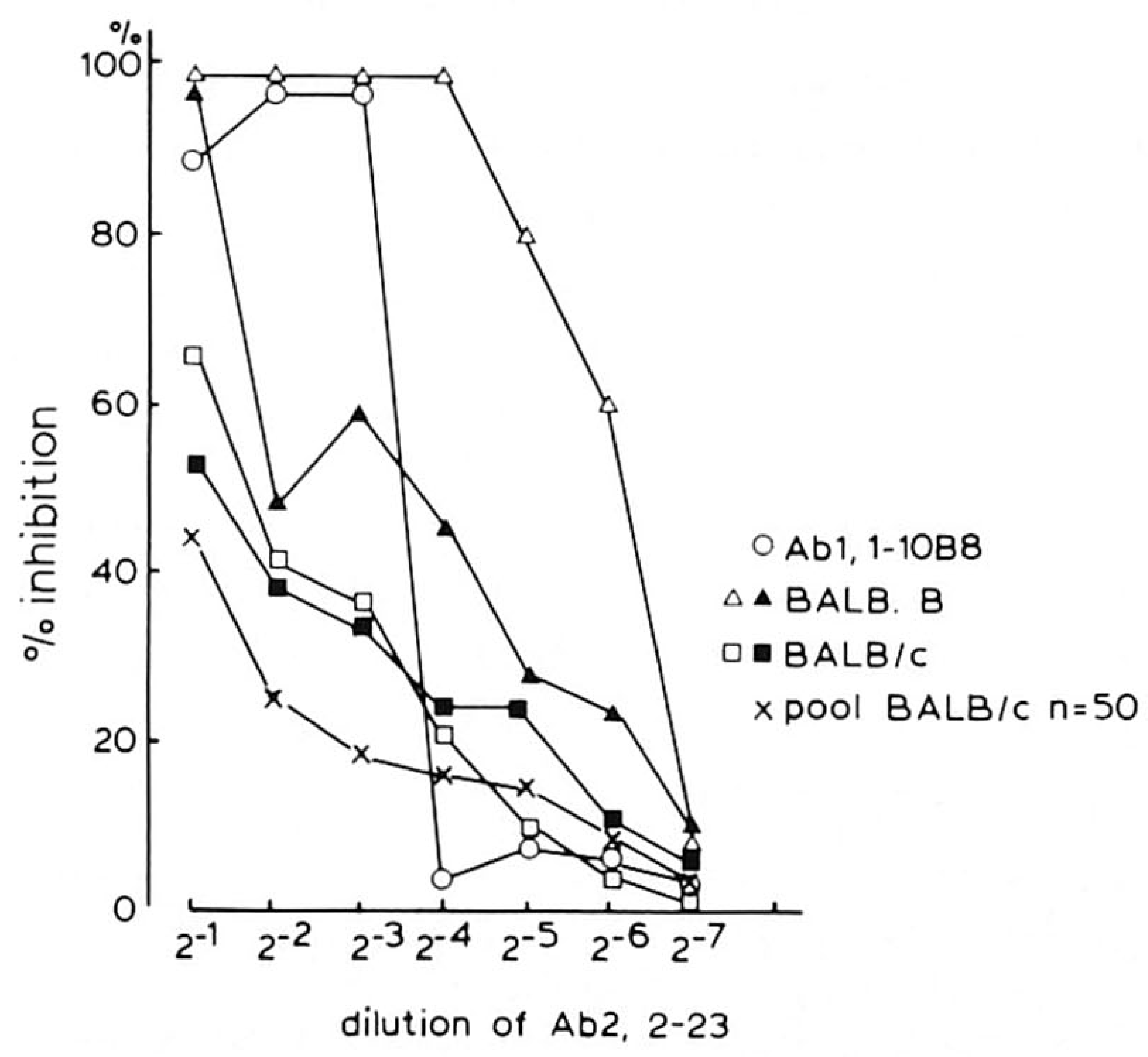

Figure 4. The proportion of anti-site-I glycoprotein antibodies bearing the MoAb1, 1-10B8 idiotope in a rabies virus-induced response. ELISA; inhibition of binding of anti-site-I glycoprotein Ab1 to plate-bound rabies virus by MoAb2, 2-23. 
1-10B8 rabies virus-specific antibody-producing cells in normal BALB/c mice and of the kinetics of a primary response against rabies virus glycoprotein site$\mathrm{I}$, both at the idiotope and epitope level, are required to address this problem. Preliminary experiments, however, did not reveal indications for increased levels of $\mathrm{Ab} 1,1-10 \mathrm{~B} 8$ idiotope-bearing Ig molecules in normal $\mathrm{BALB} / \mathrm{c}$ mice.

Recently, a model for the emergence of recurrent idiotopes has been proposed by Urbain and coworkers (Urbain et al. 1985). These authors suggested that recurrent idiotopes are anti-idiotypic antibodies for antibodies against self-antigens. The immune system would be programmed to preferentially produce the recurrent idiotope because its target anti-self antibody is suppressed. Clones bearing other idiotopes but having the same epitope specificity would be less favored because their "preferred" partners are not suppressed.

This hypothesis led us to assume that the target anti-self antibody for the MoAb1, 1-10B8 idiotope displays specificity for the nicotinic acetylcholine receptor (AChR). The following experimental data support this assumption. First, it has been documented that AChR has sites accessible to interact with rabies virus (Lentz et al. 1982, Burrage et al. 1985). In addition to morphological and biochemical evidence, Burrage and coworkers also provided immunological evidence for rabies virus glycoprotein binding to AChR. In the course of these studies the authors observed that auto-anti-idiotypic antibodies against rabies virus neutralizing antibodies, detectable in sera of mice immunized with rabies virus glycoprotein, not only reduced the rabies virus neutralizing capacity of serum antibodies but also bound to $\mathrm{AChR}$. Apart from interpreting these results on the basis of $\mathrm{Ab} 2 \beta$ which mimics rabies virus epitopes, resulting in reduced neutralization, one could argue that the population of neutralizing antibodies contains Abl-bearing recurrent idiotypes exhibiting anti-idiotypic specificity for anti-AChR antibodies. Our observations that 2 different rabbit anti-idiotypic antibody preparations against a rat monoclonal anti-AChR react with rabies virus strengthens these reports (de Baets and UytdeHaag, unpublished observations). Evidence has been obtained suggesting that, in case of infection with rabies virus, primary virus replication occurs in muscle tissue (Murphy \& Bauer 1974). The pathological changes following infection may also affect the post-synaptic membrane on the neuromuscular junction bearing AChR. When AChR material becomes accessible to the immune system it will trigger the onset of an autoantibody response leading to myasthenia gravis (see Lindstrom for review). There is evidence that this autoimmune response is subject to regulation by auto-antiidiotypic antibodies (Cleveland et al. 1983, Dwyer et al. 1983). It would be most efficient if, in case of infection with rabies virus, the answer of the immune system were to serve a dual purpose, i.e. prevention of virus spread and suppression of an autoimmune response. Secondly, it appeared to be rather difficult to generate syngeneic MoAb2-producing hybridomas defining interstrain (MoAb2, 2-23) or interspecies recurrent idiotopes (MoAb2, 2-17 see next section). However, syn- 
geneic MoAb2 defining private idiotopes could be generated relatively easily in the FeLV system. In accordance with Urbain's hypothesis, clones producing Ab2 against recurrent idiotopes would display anti-self specificity and as a consequence would be suppressed.

Finally, it has been reported that in experimental autoimmune myasthenia gravis in mice, disease susceptibility is associated with the $\mathrm{H} 2^{\text {b }}$ haplotype (Berman \& Patrick 1980). If MoAb1, 1-10B8 were indeed to be anti-idiotypic for anti-AChR antibody, the relatively high expression of MoAb1, 1-10B8 after rabies virus immunization in BALB.B. mice, as compared to BALB/c mice, could be explained by the association of disease susceptibility with the $\mathrm{H} 2^{\mathrm{b}}$ haplotype (Fig. 4).

We are now validating this concept which, if it turns out to be correct, may have far-reaching implications for the practical applicability of such MoAb2 as vaccines.

\section{AB2 AGAINST INTERSPECIES RECURRENT IDIOTOPES OR REPRESENTING INTERNAL IMAGES OF EPITOPES (POLIOVIRUS AS A MODEL)}

Nisonoff and Lamoyi have proposed that $\mathrm{Ab} 2 \beta$ representing internal images of original epitopes are probably the best candidate vaccines. As structural data on $\mathrm{Ab} 2 \beta$ are not available, it's impossible to say whether antigen-specific responses mediated by $\mathrm{Ab} 2 \beta$ reflect real structural homology between $\mathrm{Ab} 2 \beta$ and epitopes. Therefore it may be more appropriate to define $\mathrm{Ab} 2 \beta$ by criteria formulated by Nisonoff \& Lamoyi (1981).

i. Ab $2 \beta$ should react with antigen-specific Abl from different species and the reaction between $\mathrm{Ab} 2$ and $\mathrm{Ab} 1$ should be antigen-inhibitable;

ii. Ab $2 \beta$ should be able to induce antigen-specific response in different species.

A still expanding number of reports provide evidence for the existence of Ab2 $\beta$ able to modulate specific immunity in various models of infectious diseases (for reviews see Kennedy 1985, Reagan 1985, UytdeHaag \& Osterhaus 1985, Sacks 1985, Stein 1985, Urbain 1985, Green et al. 1985, Ertl \& Finberg 1984, McNamara et al. 1984, Roehring et al. 1985, Grzych et al. 1985, Thanavala et al. 1985).

We have been able to induce poliovirus type II neutralizing antibodies in $\mathrm{BALB} / \mathrm{c}$ mice using MoAb2-defining paratope-related and interspecies-recurrent idiotopes on anti-poliovirus type II neutralizing antibodies (UytdeHaag \& Osterhaus 1985a, 1985b). We have chosen poliovirus as a model for MoAb2-induced immunity because humoral immunity is the major component of the protective immune response against infection with poliovirus. Furthermore, the assumed limited number of neutralization-inducing epitopes on poliovirus (Fergusson et al. 1984, Evans et al. 1983) would allow the use of only a limited panel of MoAb2 as a vaccine. The demonstration that mice treated with one single inoculation of 1 monoclonal neutralizing anti-poliovirus type II antibody are protected against 
a lethal challenge with the virus strengthens this assumption (UytdeHaag \& Osterhaus 1985b). Finally, a recently developed in vitro system for the induction and measurement of a poliovirus-specific neutralizing antibody response using human peripheral blood lymphocytes (UytdeHaag et al., 1985) will offer an opportunity to study the Ab2-induced humoral immune response in man.

\section{Generation and characterization of MoAb2, 2-17C3scc}

A MoAbl (1-10 C9E8) was selected from a panel of MoAbl because it defined a major neutralization-inducing epitope on poliovirus type II strain MEF1 (Osterhaus et al. 1981a, 1981b, 1983, UytdeHaag \& Osterhaus 1985b).

In order to obtain syngeneic MoAb2, BALB/c mice were immunized with purified MoAb1, 1-10C9E8. One out of 5 clones, MoAb2, 2-17C3scc obtained in 3 independent fusions showed strong anti-idiotope reactivity for MoAbl, 1-10C9E8. This idiotope was found to be closely associated with, or to be located within the paratope of Ab1, 1-10C9E8, since the binding of MoAb2, 2-17C3scc to MoAb1, 1-10C9E8 could completely be inhibited by poliovirus type II. The use of other Ab1 probes revealed evidence that MoAb2, 2-17C3scc defined an interspecies recurrent idiotope on anti-poliovirus antibodies. MoAb2 2-17C3scc reacted not only with MoAb1, 1-10C9E8 but also with 2 other poliovirus type II neutralizing MoAbl which derived from different fusions. Subsequently it was found that MoAb2, 2-17C3cc bound specifically to poliovirus type II neutralizing antibodies of $\mathrm{BALB} / \mathrm{c}$ mice, rats, guinea pigs and human individuals immunized with poliovirus.

\section{Immunization with MoAb2, 2-17C3scc induces poliovirus-neutralizing antibodies}

Because MoAb2, 2-17C3scc possibly bears a poliovirus-related epitope or defines an interspecies recurrent idiotope, experiments were carried out aimed at the induction of protective immunity against poliovirus. BALB/c mice were immunized with different doses of Ab2 in saline. Their sera were analyzed for Ab3 antibodies and poliovirus-neutralizing antibodies. As shown in Table VI, sera from 4 out of 8 mice (expressing Ab3 after inoculation with MoAb2, 2-17C3scc) could neutralize poliovirus type II infectivity. However, neutralizing titers on these animals were too low to protect against a lethal challenge with the MEF1 strain of poliovirus type II. MoAb2, 2-17C $3 \mathrm{scc}$ itself contains no poliovirusneutralizing activity and does not act as a polyclonal activator. Thus it can be concluded that MoAb2, 2-17C3scc has expanded poliovirus-specific B cell clones. It cannot be determined by serological means whether this induction is the result of selection by poliovirus-related epitopes on $\mathrm{Ab} 2(\mathrm{Ab} 2 \beta)$ or is mediated through selection by Ab2a of clones bearing the 1-10C9E8 interspecies recurrent idiotope, which binds the virus. 
TABLE VI

MoAb2, 2-17C3scc induce poliovirus neutralizing antibodies in BALB/c mice

\begin{tabular}{lccc}
\hline Immunogen & Number of mice & $\begin{array}{c}\text { Poliovirus } \\
\text { neutralizing Ab }\end{array}$ & $\begin{array}{c}\text { Survival after } \\
\text { challenge (days) }\end{array}$ \\
\hline $\begin{array}{c}\text { MoAb2, 2-17C3scc } \\
5 \mu \mathrm{g}\end{array}$ & 2 & 32 & 5,10 \\
$500 \mathrm{ng}$ & 2 & 32 & 10,11 \\
$50 \mathrm{ng}$ & 2 & $<2$ & 9,12 \\
$5 \mathrm{ng}$ & 2 & $<2$ & 8,7 \\
$\mathrm{MoAb1}, 10-10 \mathrm{C} 9 \mathrm{E}^{\mathrm{a}}$ & 2 & & $>25$ \\
$5 \mu \mathrm{gg}$ & 2 & 2048 & $>25$ \\
$500 \mathrm{ng}$ & 2 & 128 & $>25$ \\
$50 \mathrm{ng}$ & 2 & 8,2 & 15,13 \\
$5 \mathrm{ng}$ & 2 & & \\
\hline
\end{tabular}

a MoAb1, 1-10C9E8 was used with a neutralizing titer of $10^{4.9} / 50 \mu \mathrm{l}$ using $100 \mathrm{TCID}_{50}$. Mice were injected $24 \mathrm{~h}$ prior to challenge with $\mathrm{LD}_{50}$ of poliovirus type II strain MEF1. (UytdeHaag \& Osterhaus 1985b).

\section{SUMMARY AND CONCLUDING REMARKS}

The present paper describes experiments which evaluate the potential of MoAb2 directed against either private or recurrent idiotopes as vaccines.

We focused our attention on the generation of monoclonal anti-idiotypic preparations because, both for the purpose of generating antibodies of predefined specificity and for practical technological reasons, polyclonal anti-idiotypic preparations cannot be used. Although the use of monoclonal preparations for such vaccines seems to be inevitable, the present studies clearly demonstrate that the immune response elicited by injection of single MoAb2 against either private or recurrent idiotopes is significantly inferior to responses generated by viral antigens.

In the FeLV system, where MoAb2, 2-17 defines a paratope-related private idiotope of MoAb1, 3-17, immunization with MoAb2, 2-17 coupled to LPS (or $\mathrm{KLH}$ ) induced Ab3 sharing idiotope but not anti-FeLV specificity with MoAb1, 3-17. Recently, it has been reported by Legrain and coworkers (Legrain et al. 1985, Sanchez \& Legrain 1985) that immunization with a single MoAb2 (coupled to LPS or KLH) defining a private idiotope of ABPC48 levan-binding myeloma protein (IDA17) was ineffective in inducing idiotope-positive (Id17) anti-levan antibody. However, when in addition to IDA17, 2 other MoAb2 defining recurrent idiotopes of ABPC48 (IDA10 and IDA16) were injected, mice produced antibodies binding to each of the MoAb2 and exhibiting anti-levan activity. The induction of these ABPC48-like antibodies was only obtained when the $3 \mathrm{MoAb} 2$, IDA10, 16 and 17 were injected in sequence. A single immunization with a 
mixture of IDA10, 16 and 17 induced the expression of Id10, 16 and 17, respectively, devoid of levan-binding activity. These data show that expression of Id17 on antibodies with specificity for levan is associated with the expression of the 2 other idiotopes, Id 10 and Id 16, and indicate that ABPC48-like antibody can only be induced by sequential immunization with the respective MoAb2.

The information gained from the ABPC48 system may be important for the interpretation of our results obtained in the FeLV and rabies virus system. The failure to induce FeLV binding antibody by MoAb2, 2-17 in spite of a vigorous Ab3 response could simply reflect the activation of too low a number of B cell percursors for detection in our assays. Also, in this system sequential immunization of mice with MoAb2 defining different non-overlapping idiotopes of MoAb1, 3-17 may help to expand, more selectively, clones of the desired specificity.

The situation in the rabies virus system may be different because if, as proposed by Urbain and coworkers (Urbain et al. 1985), antibodies bearing recurrent idiotypes like MoAb, 1-10B8 are indeed anti-idiotypic for anti-self antibodies, other idiotype-bearing antibodies will be less favored (or not expressed at all) because their "preferred partners" are not suppressed. This would explain why, in contrast to the FeLV system, low levels of anti-rabies virus antibodies are induced in "appropriate" strains of mice (IghVa) by injection of MoAb2, 2-23. The use of more MoAb2 defining other idiotopes of MoAb1, 1-10B8 may help to increase anti-rabies virus response in $\mathrm{IghV}^{\mathrm{a}}$-bearing mice and may activate silent or private 1-10B8 idiotope-bearing clones exhibiting anti-rabies virus activity in the repertoire of "inappropriate" strains of mice and even in the repertoire of other species. Clearly, future research should be focused on the sequential immunization with different MoAb2a in these systems and on the search for alternatives to polyclonal activators coupled to these antibodies.

In contrast to $\mathrm{Ab} 2$ in the FeLV and rabies virus systems, the behavior of MoAb2, 2-17C3scc defining a paratope-related idiotope of a poliovirus type II neutralizing MoAb1, 1-10C9E8 seems to be consistent with the internal image (Ab2 $\beta$ ) concept. MoAb2, 2-17C3scc proved to react with poliovirus hyperimmune sera from different animal species and was shown to elicit anti-poliovirus type II neutralizing antibody in $\mathrm{BALB} / \mathrm{c}$ mice. The lack of protective immunity in this system may reflect the general feature of $\mathrm{Ab} 2 \beta$, that internal images per se are poor immunogens. Indeed it has been shown in other systems that for an efficient induction of protective immunity the MoAb2 had to be coupled to immunogenic carriers (McNamara et al. 1984). Thus, immunization experiments in different animal species with MoAb2, 2-17C3scc coupled to immunogenic substances may further prove that MoAb2, 2-17C3scc indeed represents an internal image of a neutralization-inducing epitope of poliovirus type II. However, only sequence data and/or X-ray crystallography may unequivocally distinguish it from a MoAb2a defining an interspecies recurrent idiotope. 


\section{ACKNOWLEDGMENTS}

We are greatly indebted to Jacques Urbain and coworkers for advice and stimulating discussions. We thank Dr. Yang Hongju and our students Ch. Bodar, M. Jansen, J. Jacobs, F. Heemskerk, J. Wagenaar, and T. Glaudemans for their important contributions to the results presented in this paper. The expert technical assistance of G. Drost, R. Bakker, K. Siebelink and H. Loggen is gratefully acknowledged. We wish to thank C. Kruyssen for preparing the manuscript. This work was supported in part by a fellowship of the World Health Organization and by a grant (8503) from the European Veterinary Laboratory, Amsterdam, The Netherlands.

\section{NOTE ADDED IN PROOF}

Since the submission of this manuscript we observed that the BALB/c mice immunized with Ab2, 2-17 copolymerized with LPS (see table III) did develop anti-FeLV antibodies 20 weeks after inocculation (Osterhaus et al. manuscript submitted).

\section{REFERENCES}

Berman, P. W. \& Patrick, J. (1980) Linkage between the frequency of muscular weakness and loci that regulate immune responsiveness in immune experimental autoimmune myasthenia gravis. J. Exp. Med. 152, 507.

Bluestone, J. A., Epstein, S. L., Ozato, K., Sharron, S. O. \& Sacks, D. H. (1981) Antiidiotypes to monoclonal anti-H-2 antibodies II. Expression of anti-H-2 $\mathrm{K}^{\mathrm{k}}$ idiotypes on antibodies induced by anti-idiotype or $\mathrm{H}-2 \mathrm{~K}^{\mathrm{k}}$ antigen. J. Exp. Med. 154, 1365.

Bolognesi, D. P., Montelaro, R. C., Frank, H. \& Schäfer, W. (1978) Assembly of type-c oncorna viruses: a model. Science 199, 183.

Bona, C. A., Finley, S. Waters, S. \& Kunkel, H. G. (1982) Anti-immunoglobulin antibodies III. properties of sequential anti-idiotypic antibodies to heterologous anti-globulins. Detection of reactivity of anti-idiotype antibodies with epitopes of $\mathrm{FC} \gamma$ fragments (homobodies) and with epitopes and idiotopes (epibodies). J. Exp. Med. 156, 986.

Bona, C. A., Heber-Katz, E. \& Paul, W. E. (1981) Idiotype-anti-idiotype regulation. I. Immunization with a levan-binding myeloma protein leads to the appearance of autoanti-antibodies and to the activation of silent clones. J. Exp. Med. 153, 951.

Burrage, T. G., Tignor, G. H. \& Smit A. L. (1985) Rabies virus binding at neuromuscular junctions. Virus res. $2,273$.

Cazenave, P. A. (1977) Idiotypic-anti-idiotypic regulation of antibody synthesis in rabbits. Proc. Natl. Acad. Sci (USA) 74, 5122.

Chen, P. P., Fong, S., Houghten, R. A. \& Carson, D. A. (1985) Characterization of an epibody. An anti-idiotype that reacts with both the idiotype of rheumatoid factors (RF) and the antigen recognized by RF. J. Exp. Med. 161, 323.

Cleveland, W. L., Wassermann, N. H., Sarangarajan, R., Penn, A. S. \& Erlanger, B. F. (1983) Monoclonal antibodies to the acetylcholine receptor by a normally functioning auto-anti-idiotypic mechanism. Nature $\mathbf{3 0 5}, 56$. 
Cox, J. H., Dietzschold, B. \& Schneider, L. G. (1977) Rabies virus glycoprotein. II. Biological and serological characterization. Infect. Immun. 16, 754.

Dwyer, D. S., Bradley, R. J., Urquhart, C. U. \& Kearney, J. F. (1983) Naturally occurring anti-idiotypic antibodies in myasthenia gravis patients. Nature 301, 611.

Eichman, K. (1974) Idiotype supression. I. Influence of the dose and of the effector functions of anti-idiotypic antibody on the production of an idiotype. Eur. J. Immunol. 4, 296.

Ertl, H. C. J. \& Finberg, R. W. (1984) Sendai virus-specific T cell clones: induction of cytolytic $\mathrm{T}$ cells by an anti-idiotypic antibody directed against a helper $\mathrm{T}$ cell clone. Proc. Natl. Acad. Sci. USA 81, 2850.

Evans, D. M., Minor, P. D., Schild, G. S. \& Almond, J. W. (1983) Critical role of an eight amino acid sequence of VP1 in neutralization of poliovirus type III. Nature 304, 459.

Fergusson, H., Minor, P. D., Margrath, P. I., Qui Yi-Hua, Spitz, M. \& Schild, J. C. (1984) Neutralizing epitopes on poliovirus type 3 particles: an analysis using monoclonal antibodies. J. Gen. Virol. 65, 197.

Francotte, M. \& Urbain, J. (1984) Induction of anti-tobacco mosaic virus antibodies in mice by rabbit anti-idiotypic antibodies. J. Exp. Med. 160, 1485.

Gerin, J. L., Alexander, H., Shih, J. W. K., Purcell, R. H., Dapolito, G., Engle, R., Green, N., Sutcliffe, J. G., Shinnick, T. M. \& Werner, R. A. (1983) Chemically synthesized peptides of hepatitis B surface antigen duplicate the d/y specificities and induce subtype-specific antibodies in chimpanzees. Proc. Natl. Acad. Sci (USA) 80, 2365.

Goebel, W. F. Chemo-immunological studies on conjugated carbohydrate proteins: immunochemical properties of artificial antigen containing cellobiuronic acid. J. Exp. Med. 68, 469.

Grant, C. K., de Noronha, F., Tusch, C., Michalek, M. T. \& McLane, M. F. (1980) Protection of cats against progressive fibrosarcoma and persistent leukemia virus infection by vaccination with feline leukemia cells. JNCI $\mathbf{6 5}, 1285$.

Green, M. I., Weiner, H. L., Dichter, M. \& Fields, B. N. (1984) Syngeneic monoclonal anti-idiotypic antibodies identify reovirus type 3 hemagglutinin receptors on immune and neuronal cells. Receptor Biochem. Methodol. 4, 177.

Grzijch, J. M., Capron, M., Lambert, P. H., Dissous, C., Torres, S. \& Capron, A. (1985) An anti-idiotype vaccine against experimental schistosomiasis. Nature 316, 74.

Hiernaux, J., Bona, C. \& Baker, P. J. (1981) Neonatal treatment with low doses of antiidiotypic antibody leads to the expression of a silent clone. J. Exp. Med. 153, 1004.

Jerne, N. K. (1974) Towards a network theory of the immune system. Ann. Immunol. (Paris) 125c, 373.

Jerne, N. K., Roland, J. \& Cazenave, P. A. (1982) Recurrent idiotopes and internal images. EMBO J. 1, 243.

Kennedy, R. C. (1985) Idiotype networks in hepatitis B virus infections. Curr. Top. Microbiol. Immunol. 119, 1.

Lafon, M., Wiktor, T. J. \& Macfarlan, R. I. (1983) Antigenic sites on the CVS rabies virus glycoprotein: analysis with monoclonal antibodies. J. Gen. Virol. 64, 843.

Legrain, P., Sanchez, P. \& Buttin, G. (1985) Immune response induced by a single or several syngeneic monoclonal anti-ABPC48 anti-idiotypic antibodies: no predominant coexpression of ABPC48 idiotopes. J. Mol. Immunol. 22, 445.

Lentz, T. L., Burrage, T. G., Smit, A. L., Crick, J. \& Tignor, G. H. (1982) Is the acetylcholine receptor a rabies virus receptor? Science $\mathbf{2 1 5}, 182$.

Lerner, R. A. (1982) Tapping the immunological repertoire to produce antibodies of predetermined specificity. Nature 299, 592.

Lindstrom, J. (1984) Nicotinic acetyl-choline receptors: use of monoclonal antibodies to study synthesis, structure, function, and auto immune response. Receptor Biochem. Methodol. 4, 21. 
McNamara, M. K., Ward, R. E. \& Kohler, H. (1984) Monoclonal idiotype vaccine against streptoccocus pneumoniae infection. Science 926, 1325.

Murphy, F. A. \& Bauer, S. P. (1974) Early street rabies virus infection in striated muscle and later progression to the central nervous system. Intervirology 3, 256.

Nisonoff, A. \& Lamoyi, E. (1981) Implications of the presence of an internal image of the antigen in anti-idiotypic antibodies: possible application to vaccine production. Clin. Immunol. Immunopathol. 21, 397.

Osterhaus, A. D. M. E., van Wezel, A. L., Hazendonk, T. G., UytdeHaag, F. G. C. M., van Asten, J. A. A. M., van Steenis, B., (1983). Monoclonal antibodies to polioviruses. Comparison of intratypic strain differentiation of poliovirus type 1 using monoclonal antibodies versus cross-absorbed antisera. Intervirology 20, 119.

Osterhaus, A. D. M. E., van Wezel, A. L., van de Marel, P., van Steenis, G., (1981a). Production of monoclonal antibodies against poliomyelitis and rabies viruses. In: (Peeters, H., ed.) Prot. of the Biol. FL. Proceed. of the twenty-ninth coll. 29, 743, Pergamon Press, N. Y.

Osterhaus, A. D. M. E., van Wezel, A. L., van Steenis, B., Drost, G. A., Hazendonk, T. G., (1981b). Monoclonal antibodies to polioviruses: production of specific monoclonal antibodies to the sabin vaccine strains. Intervirology 60, 218.

Osterhaus, A., Weyer, K., Uytdcllaag, F., Jarrett, O., Sundquist, B. \& Morein, B. (1985) Induction of protective immune response in cats by vaccination with feline leukemia virus iscoms. J. Immunol. 135, 591.

Pene, J., Bekkhoucha, F., Desaymark, C., Zaghouani, H. \& Stanislawski, M. (1983) Induction of a cross-reactive idiotype dextran-positive antibody response in two $\operatorname{IgH}-\mathrm{C}^{\mathrm{b}}$ mouse strains treated with anti-J558 cross-reactive idiotype antibodies. J. Exp. Med. $157,1573$.

Quinnan, G. V. (ed.) (1985) Vaccinia viruses as vectors for vaccine antigens. In: Proc. workshop on vaccinia viruses as vectors for antigens. Elsevier Sci. Publ. Co. Inc., New York.

Rajewsky, K. \& Takemori, T. (1983) Genetics, expression and function of idiotypes. Ann. Rev. Immunol. 1, 596.

Reagan, K. J. (1985) Modulation of immunity to rabies virus induced by anti-idiotypic antibodies. Curr. Top. Microbiol. Immunol. 119, 15.

Roehring, J. T., Hunt, A. R. \& Matheus, J. H. (1984) Identification of anti-idiotype antibodies that mimic the neutralization site of Venezuelean equine encephalomyelitis. In: high Technology route to virus vaccines. Houston Abstr. p. 32.

Rubinstein, J. L. \& Bona, C. A. (1983) Idiotype-anti-idiotype network. II. Activation of silent clones by treatment at birth with idiotypes is associated with the expansion of idiotype-specific helper T cells. J. Exp. Med. 156, 506.

Sacks, D. L. (1985) Molecular Mimicry of parasite antigens using anti-idiotypic antibodies. Curr. Top. Microbiol. Immunol. 119, 45.

Sacks, D. L., Kelsoe, G. H. \& Sacks, D. H. (1983) Induction of immune responses with anti-idiotypic antibodies: implications for the induction of protective immunity. Springer Semin. Immunopathol. 6, 79.

Sacks, D. L. \& Sher, A. (1983) Evidence that anti-idiotype induced immunity of African trypanasomiasis is genetically restricted and requires recognition of combining site related idiotopes. J. Immunol. 131, 1511.

Sanchez, P. \& Legrain, P. (1985) The expression of a private idiotope requires pretreatment with non-complementary anti-idiotypic antibodies. Mol. Immunol. 22, 1231.

Slaoui, M., Urbain, J., Lowy, A., Monroe, J., Benacerraf, B. \& Green, M. (1985) Antiidiotypic treatment of $\mathrm{BALB} / \mathrm{c}$ mice induces $\mathrm{CRI}_{\mathrm{A}}$ bearing suppressor cells and changes the predicted Igh restriction pattern. J. Immunol. (in press). 
Stein, K. E. (1985) Network regulation of the immune response to bacterial polysaccharide antigens. Curr. Top. Microbiol. Immunol. 119, 57.

Stewart-Tull, D. E. S. (1985) Immuno-potentiating conjugates. Vaccine 3, 41.

Takemori, T., Tesch, H., Reth, M. \& Rajewsky, K. (1982) The immune response against anti-idiotope antibodies. I. Induction of idiotope-bearing antibodies and analysis of the idiotope repertoire. Eur. J. Immunol. 12, 1040.

Thanavala, Y. M., Bond, A., Tedder, R., Hay, F. C. \& Roitt, I. M. (1985) Monoclonal "internal image" anti-idiotypic antibody of hepatitis B surface antigen. Immunology 55, 197.

Trenkner, E. \& Riblet, R. (1975) Induction of anti-phosphorylcholine antibody formation by anti-idiotypic antibodies. J. Exp. Med. 142, 1121.

Urbain, J. (1985) Idiotypic networks: a noisy background or a breakthrough in immunological thinking. The broken mirror hypothesis. Ann. Immunol. (Paris) (in press).

Urbain, J., Brait, M., Bruyns, C., Demeur, C., Dubois, P., Francotte, M., Franssen, J. D., Hiernaux, J., Leo, O., Marvel, J., Meyers, P., Moser, M., Slaoui, M., Tassignon, J., Urbain-Vansanten, G., Van Acker, A., Wikler, M., Willems, F. \& Wuilmart, C. (1985) The idiotypic network: order out of the beginning or order out of chaos? Curr. Top. Microbiol. Immunol. 11, 125.

Urbain, J., Francotte, M., Franssen, J. D., Hiernaux, J., Leo. O., Moser, M., Slaoui, M., Urbain-Vansanten, G., van Acker, A. \& Wikler, M. (1983) From clonal selection to immune networks: Induction of silent idiotypes. Ann. NY Acad. Sci 418, 1.

Urbain, J., Wikler, M., Franssen, J. D. \& Collignon, C. (1977) Idiotypic regulation of the immunesystem by the induction of antibodies against anti-idiotypic antibodies. Proc. Natl. Acad. Sci. (USA) 74, 5126.

UytdeHaag, F. G. C. M., Loggen, H. G., Logtenberg, T., Lichtveld, R. A., van Steenis, B., van Asten, A. A. M. \& Osterhaus, A. D. M. E. (1985) Human peripheral blood lymphocytes from recently vaccinated individuals produce both type-specific and intertypic crossreacting neutralizing antibody on in vitro stimulation with one type of poliovirus. J. Immunol. 135, 3094.

UytdeHaag, F. C. G. M. \& Osterhaus, A. D. M. E. (1985a) Vaccines from monoclonal anti-idiotypic antibody: poliovirus infection as a model. Curr. Top. Microbiol. Immunol. 119,31 .

UytdeHaag, F. G. C. M. \& Osterhaus, A. D. M. E. (1985b) Induction of neutralizing antibody in mice against poliovirus type II with monoclonal anti-idiotypic antibody. J. Immunol. 134, 1225.

Wikler, M., Fransen, J. D., Collignon, C., Leo, O., van de Walle, M., De Groote, D. \& Urbain, J. (1979) Idiotypic regulation of the immune system: common idiotypic specificities between idiotypes and antibodies raised against anti-idiotypic anti-bodies in rabbits. J. Exp. Med. 150, 184.

Wiktor, T. J., Kamo, I. \& Koprowski, H. (1974) In vitro stimulation of rabbit lymphocytes after immunization with live and inactivated rabies vaccines. J. Immunol. 112, 2013.

Wiktor, T. J., Macfarlan, R. I., Foggin, C. M. \& Koprowski, H. (1984b) Antigenic analysis of rabies and mokola virus from Zimbabwe using monoclonal antibodies. Develop. Biol. Stand. 57, 199.

Wiktor, T. J., Macfarlan, R. I., Reagan, K. J., Dietzsschold, B., Curtis, P. J., Wunner, W. H., Kieny, M. P., Lathe, R., Lecocq, J. P., Mackett, M., Moss, B. \& Koprowski, H. (1984a) Protection from rabies by a vaccinia virus recombinant containing the rabies virus glycoprotein gene. Proc. Natl. Acad. Sci. (USA) 81, 7194. 